UDC 547.554:615.37:578.245.2

\title{
UNSYMMETRICAL DERIVATIVES OF GOSSYPOL: A REVIEW
}

\author{
(C) K.Z. Tilyabaev
}

\author{
A.S. Sadykov Institute of Bioorganic Chemistry, Academy of Sciences of the \\ Republic of Uzbekistan 100125, Tashkent, Uzbekistan, Mirzo Ulugbek str., 83, \\ fax: (99871)2627063, e-mail: tilyabaevkamil@mail.ru
}

\begin{abstract}
The current work is a critical review of the known information on unsymmetrical derivatives of gossypol, which suggests future research avenues that warrant exploration.

Keywords: gossypol, unsymmetrical derivatives, synthesis, structure, biological activity.

Gossypol, 2,2'-bis(8-formyl-1,6,7-trihydroxyl-5-isopropyl-3-methylnaphthaline) (Table; 1), is a specific cottonseed pigment. Its structural as well as biological profiles have been routinely studied along with its chemical modification all throughout last century. Derivatization was found very effective to reduce the toxicity of gossypol, which was limiting the application of cottonseed meal as a fodder in agriculture. Due to the symmetry of the starting compound, for a long time only symmetrical derivatives were available. However, at present there are a lot of data on unsymmetrical gossypol derivatives. Over the past few decades, a number of publications have reported on synthesis and biological activities of unsymmetrical gossypol derivatives. However, no comprehensive review has been performed to summarize that. Thus, the current work is a critical review of known information on unsymmetrical derivatives of gossypol, which suggests future research avenues that warrant exploration.
\end{abstract}

\section{On terminology and types of unsymmetrical gossypol derivatives}

The term unsymmetrical derivatives of gossypol first was suggested by S.A. Talipov and co-authors in 1997. They applied this term for gossypol half-Schiff bases with ammonia (Table; 2 ) and methyl amine (Table; 3) [1]. However, gossypol derivatives with only one functional substituent have been already known before their research. The most of them have been prepared from racemic gossypol without further isolation of each enantiomeric part, though now there are data on unsymmetrical derivatives of (+) and (-)-gossypol [2], which will be specified in the text.

The formation of so-called gossypol mono-products or $1: 1$ complexes/products has been periodically reported, though the latter term is not quite correct and can be also addressed to symmetrical macrocyclic products of the reaction between gossypol and diamines (Fig. 1) [3-5]. Later, after gossypol bis-Schiff bases containing different amino-substituents were synthesized [6], it became necessary to clarify, whether the compound of issue was unsymmetrical mono-derivative of gossypol or its unsymmetrical bis-derivative.

Moreover, not only the introduction of the substituent to one half of gossypol molecule or further modification of its non-substituted part with a different reagent may result in the loss of gossypol's symmetry. Assuming that dimeric structure of gossypol and its symmetrical derivatives can give rise to mixed tautomeric forms within the same molecule, they also can be considered unsymmetrical and will be discussed later.

Recently J.Yin and co-authors [7] have reported on newly synthesized gossypol O-diglycosides having substituents at positions 6 and 7'. These products with 2 unsymmetrically introduced glucose or acetylated glucose molecules as well as 4,8'-dibromo apogossypol hexamethyl ester (Fig. 9; 43) [8] can serve as another example of symmetry loss that gossypol molecule may undergo. These compounds also can be called unsymmetrical bisderivatives of gossypol, though their asymmetry is rather positional than structural.

Tiliabaev Kamil Zaitzhonovich - Junior Research Fellow, candidate of chemical sciences, tel.: (+99871) 262-35-40, e-mail: tilyabaevkamil@mail.ru
All the above-mentioned are types of unsymmetrical gossypol derivatives that, to our best knowledge, have been described so far. Further, we will discuss each type in details. 


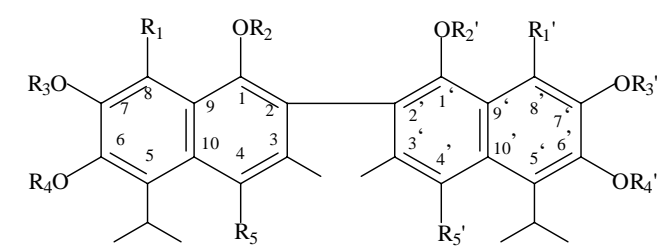

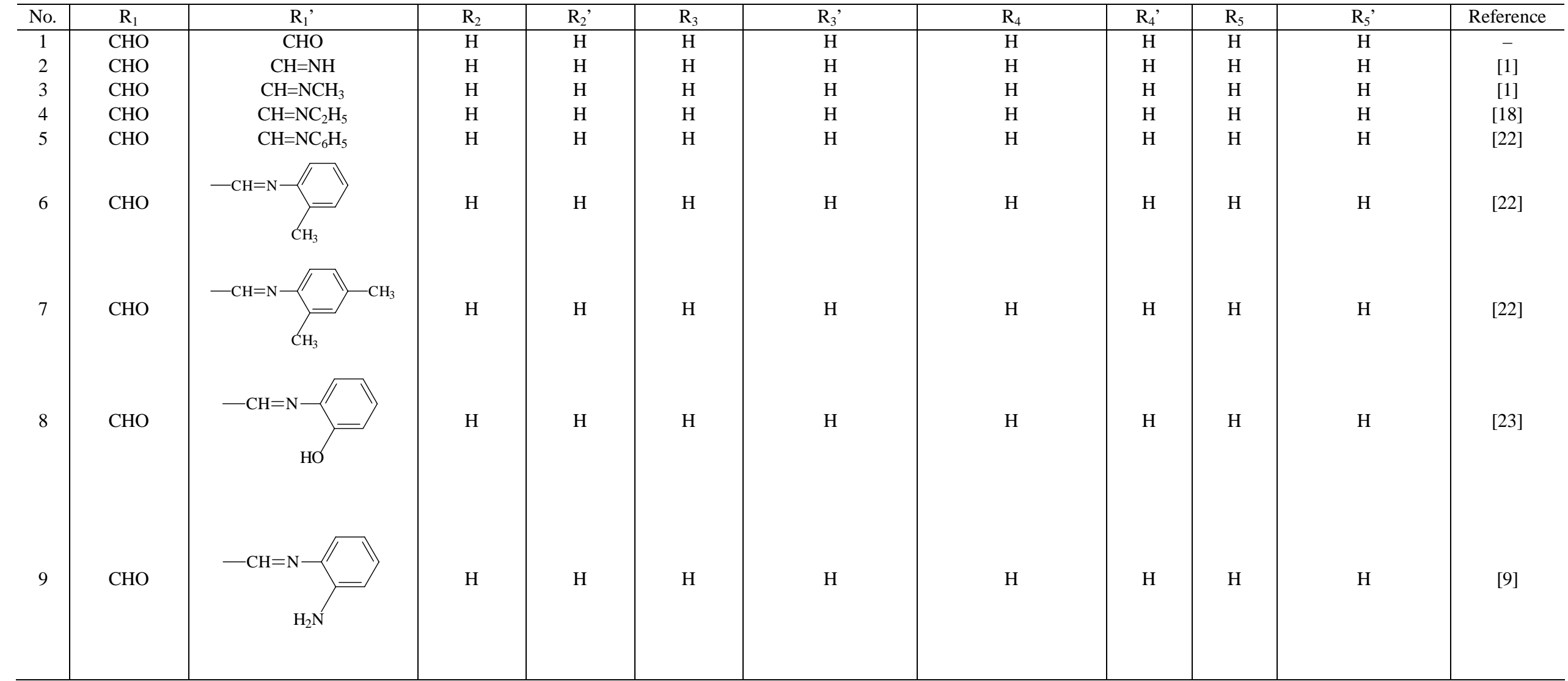


Table continued

\begin{tabular}{|c|c|c|c|c|c|c|c|c|c|c|c|}
\hline No. & R1 & R1' & R2 & R2' & R3 & R3' & $\mathrm{R} 4$ & R4' & R5 & R5' & Reference \\
\hline 10 & $\mathrm{CHO}$ & $-\mathrm{CH}=1$ & $\mathrm{H}$ & $\mathrm{H}$ & $\mathrm{H}$ & $\mathrm{H}$ & $\mathrm{H}$ & $\mathrm{H}$ & $\mathrm{H}$ & $\mathrm{H}$ & [10] \\
\hline 11 & $\mathrm{CHO}$ & & $\mathrm{H}$ & $\mathrm{H}$ & $\mathrm{H}$ & $\mathrm{H}$ & $\mathrm{H}$ & $\mathrm{H}$ & $\mathrm{H}$ & $\mathrm{H}$ & {$[24]$} \\
\hline 12 & $\mathrm{CHO}$ & & $\mathrm{H}$ & $\mathrm{H}$ & $\mathrm{H}$ & $\mathrm{H}$ & $\mathrm{H}$ & $\mathrm{H}$ & $\mathrm{H}$ & $\mathrm{H}$ & {$[25]$} \\
\hline 13 & $\mathrm{CH}=\mathrm{NC}_{6} \mathrm{H}_{5}$ & $\mathrm{CH}=\mathrm{NC}_{2} \mathrm{H}_{5}$ & $\mathrm{H}$ & $\mathrm{H}$ & $\mathrm{H}$ & $\mathrm{H}$ & $\mathrm{H}$ & $\mathrm{H}$ & $\mathrm{H}$ & $\mathrm{H}$ & [6] \\
\hline 14 & $\mathrm{CH}=\mathrm{NC}_{6} \mathrm{H}_{5}$ & $\mathrm{CH}=\mathrm{N}\left(\mathrm{CH}_{2}\right)_{2} \mathrm{CH}_{3}$ & $\mathrm{H}$ & $\mathrm{H}$ & $\mathrm{H}$ & $\mathrm{H}$ & $\mathrm{H}$ & $\mathrm{H}$ & $\mathrm{H}$ & $\mathrm{H}$ & {$[6]$} \\
\hline 15 & $\mathrm{CH}=\mathrm{NC}_{6} \mathrm{H}_{5}$ & $\mathrm{CH}_{3}$ & $\mathrm{H}$ & $\mathrm{H}$ & $\mathrm{H}$ & $\mathrm{H}$ & $\mathrm{H}$ & $\mathrm{H}$ & $\mathrm{H}$ & $\mathrm{H}$ & {$[6]$} \\
\hline 16 & $\mathrm{CH}=\mathrm{NC}_{6} \mathrm{H}_{5}$ & $\mathrm{CH}_{3}$ & $\mathrm{H}$ & $\mathrm{H}$ & $\mathrm{H}$ & $\mathrm{H}$ & $\mathrm{H}$ & $\mathrm{H}$ & $\mathrm{H}$ & $\mathrm{H}$ & {$[6]$} \\
\hline 17 & $\mathrm{CHO}$ & $\begin{array}{c}\mathrm{CH}=\mathrm{N}\left(\mathrm{CH}_{2}\right)_{4} \mathrm{CH}\left(\mathrm{NH}_{2}\right) \mathrm{CO} \\
\mathrm{OCH}_{3}\end{array}$ & $\mathrm{H}$ & $\mathrm{H}$ & $\mathrm{H}$ & $\mathrm{H}$ & $\mathrm{H}$ & $\mathrm{H}$ & $\mathrm{H}$ & $\mathrm{H}$ & [12] \\
\hline 18 & $\mathrm{CHO}$ & $\mathrm{CH}=\mathrm{NCH}\left(\mathrm{C}_{6} \mathrm{H}_{5}\right) \mathrm{COOCH}_{3}$ & $\mathrm{H}$ & $\mathrm{H}$ & $\mathrm{H}$ & $\mathrm{H}$ & $\mathrm{H}$ & $\mathrm{H}$ & $\mathrm{H}$ & $\mathrm{H}$ & [2] \\
\hline 19 & $\mathrm{CHO}$ & $\mathrm{CH}=\mathrm{NCH}\left(\mathrm{C}_{6} \mathrm{H}_{5}\right) \mathrm{COOCH}_{3}$ & $\mathrm{H}$ & $\mathrm{H}$ & $\mathrm{H}$ & $\mathrm{H}$ & $\mathrm{H}$ & $\mathrm{H}$ & $\mathrm{H}$ & $\mathrm{H}$ & [2] \\
\hline
\end{tabular}


Table continued

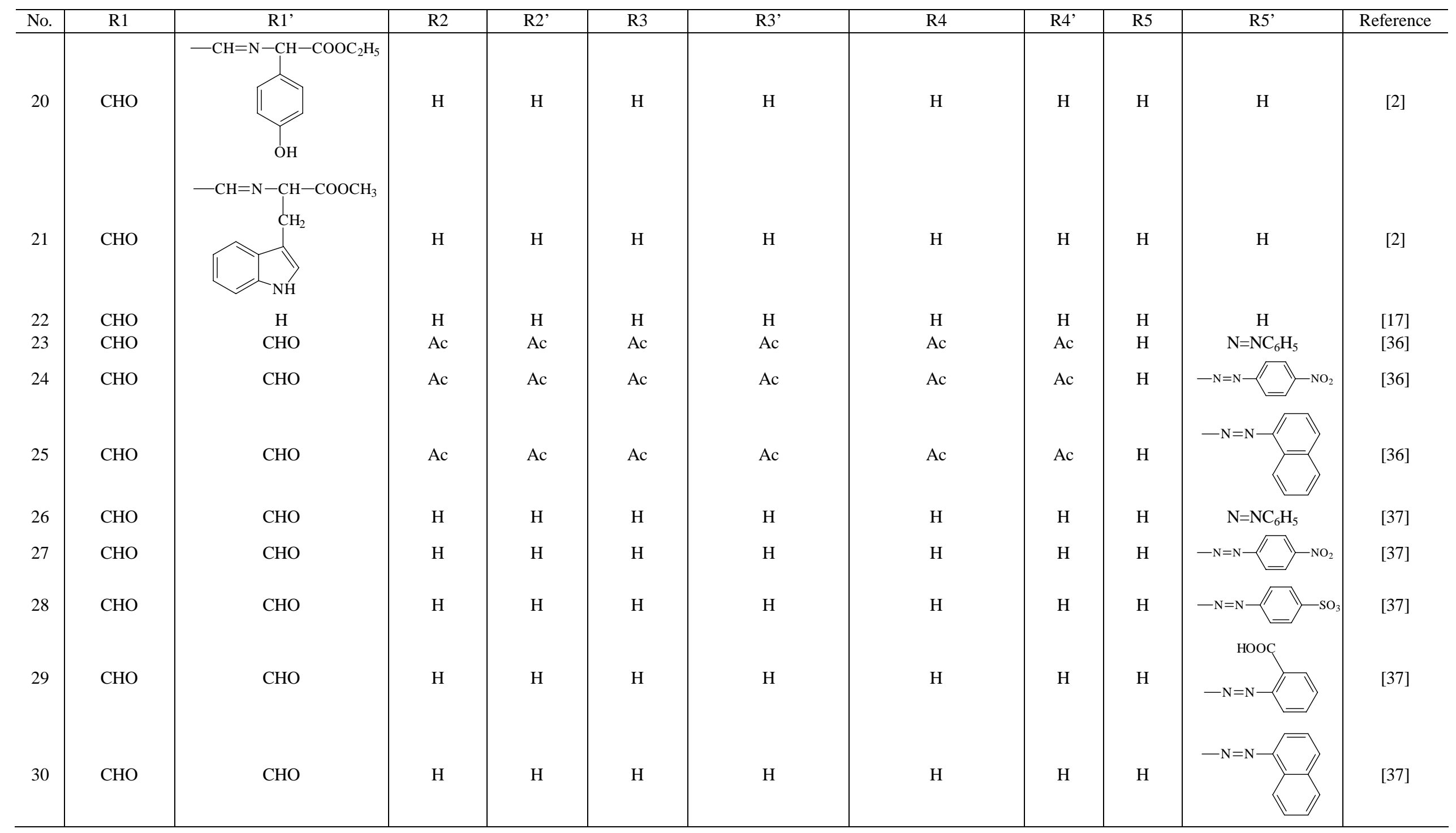


Table continued

\begin{tabular}{|c|c|c|c|c|c|c|c|c|c|c|c|}
\hline No. & R1 & R1' & R2 & R2' & R3 & R3' & R4 & R4' & R5 & $\mathrm{R}^{\prime}$ & Reference \\
\hline 31 & $\mathrm{CHO}$ & $\mathrm{CHO}$ & $\mathrm{H}$ & $\mathrm{H}$ & $\mathrm{H}$ & $\mathrm{H}$ & $\overline{\mathrm{Me}}$ & $\mathrm{H}$ & $\mathrm{H}$ & $\mathrm{H}$ & [40] \\
\hline 32 & $\mathrm{CHO}$ & $\mathrm{CHO}$ & $\mathrm{H}$ & $\mathrm{H}$ & $\mathrm{H}$ & & & $\mathrm{H}$ & $\mathrm{H}$ & $\mathrm{H}$ & [7] \\
\hline 33 & $\mathrm{CHO}$ & $\mathrm{CHO}$ & $\mathrm{H}$ & $\mathrm{H}$ & $\mathrm{H}$ & & & $\mathrm{H}$ & $\mathrm{H}$ & $\mathrm{H}$ & [7] \\
\hline
\end{tabular}

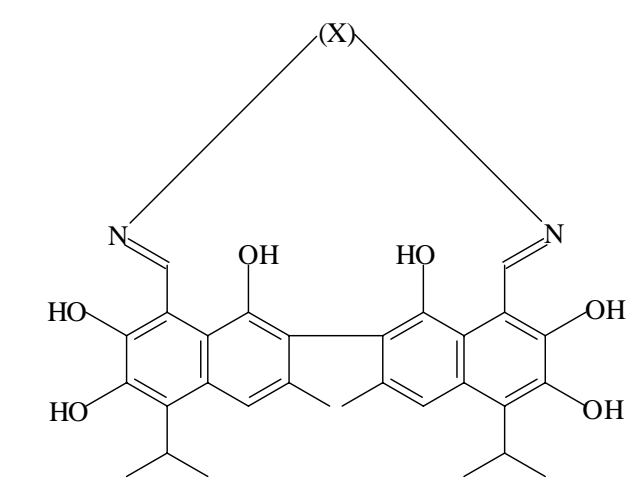

$\mathrm{X}=-\left(\mathrm{CH}_{2}\right)_{4^{-}} ;-\left(\mathrm{CH}_{2}\right)_{5^{-}} ;-\left(\mathrm{CH}_{2}\right)_{3} \mathrm{NH}\left(\mathrm{CH}_{2}\right)_{4^{-}} ;-\left(\mathrm{CH}_{2}\right)_{10^{-}} ;$

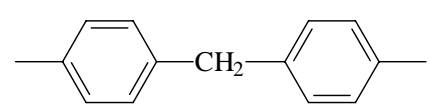

Fig.1. Macrocyclic Schiff bases of gossypol

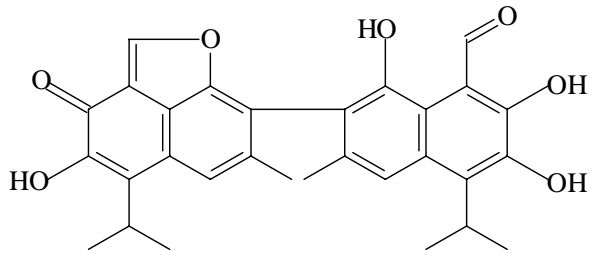

Fig. 2. Structure of mono-anhydrogossypol

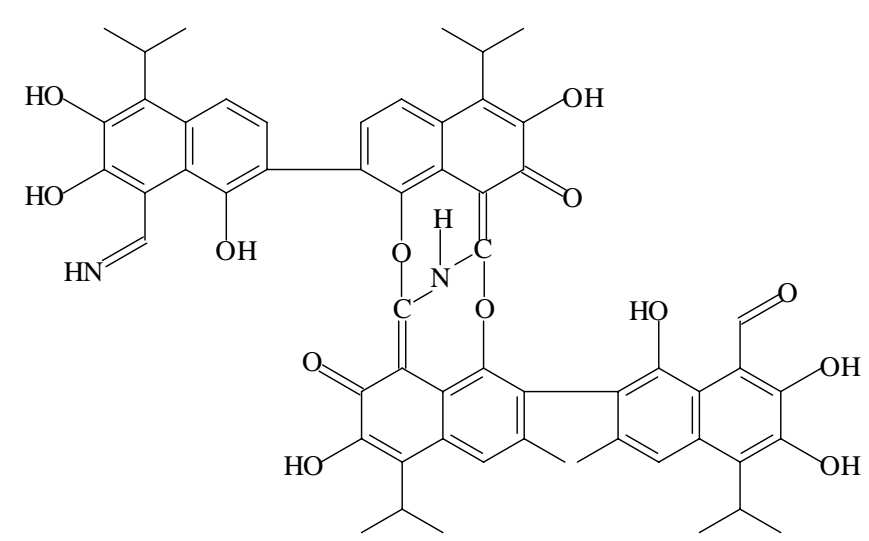

Fig.3. Structure of gossypurpurin proposed by A.I. Glushenkova with co-workers [15] 


\section{Unsymmetrical mono- and bis-derivatives of gossypol: synthesis, structure, biological properties}

Unsymmetrical mono-derivatives of gossypol can be classified according to the position or functional group in a gossypol molecule modified. Thus, there can be unsymmetrical 4 or 4'-derivatives (unsymmetrical monoazoderivatives), unsymmetrical mono-aldehyde derivatives and unsymmetrical mono-hydroxyl derivatives of gossypol. The largest group among them is gossypol mono-aldehyde derivatives.

Gossypol mono- and bis-aldehyde derivatives. Serendipitous episodic reports on mono-aldehyde derivatives of gossypol have been published since 1932, when P. Karrer and E. Tobler [9] observed the formation of monosubstituted gossypol product with o-phenylenediamine (Table; 9). This work as well as other early investigations was not performed purposefully to obtain unsymmetrical derivatives of gossypol with a certain biological activity. Moreover, due to the lack of structural research methods at that time these derivatives were not explicitly characterized in terms of structure and tautomerism. However, these works enriched our knowledge on gossypol chemistry and allowed to put light on mechanisms of its detoxification.

In 1956 J.M. Dechary and L.E. Brown [10] reported on the synthesis of $o$-nitrophenyliminogossypol (Table; 10) with $94 \%$ yield in spite of using reactants in a molar ration of gossypol to $o$-nitroaniline $1: 2$. The desired bisproduct could be obtained only by applying the large excess of amine (250\%) and 16-fold extended reaction time. A possible explanation for this anomalous behavior has not been found, however if gossypol's coupling with amines is considered as acid-base interaction, then strength and/or weakness of both has to be taken into account. It is well known that o-nitroaniline is one of the weakest bases $\left(\mathrm{pK}_{\mathrm{a}}=-0,28\right.$ [11]), so, for a successful reaction with it the reacting acid should be strong enough. Gossypol, being a diprotic acid, appears to be not sufficiently strong to react with both o-nitroaniline molecules at the conditions of mono-product formation, whereas the application of amine in a large excess allows obtaining its bis-analogue.

In 1959 P.W. Alley and D.A. Shirley [12] reported on the formation of gossypol L-lysine methyl ester $1: 1$ product (Table; 17) and, based on analytical data, suggested its structure as that of mono-substituted derivative. Even though reactants (gossypol-acetic acid and L-lysine methyl ester) were taken in a molar ratio of $1: 3,7$ respectively, the corresponding mono-product was obtained in 53\% yield. This fact can be partially explained by possible reaction of L-lysine methyl ester with acetic acid in gossypol-acetic acid complex. The resulting salt will not be able to react with gossypol due to the loss of a strong nucleophilicity by amino group. However, taking into consideration the $1: 1$ stoichiometry of gossypol-acetic acid complex [13], it is clear that at least 2,7 more moles of amino compound are still available for the interaction with each mole of gossypol. Authors did not give any reason for such a high yield of unsymmetrical gossypol derivative with L-lysine methyl ester, but it could be suggested that certain number of gossypol molecules in hot propan-2-ol used as a solvent for reaction, might form mono-acetals (Fig. 5; 34) and therefore, become partially non-attackable by amine.

The formation of mono-acetals in low molecular alcohols followed by their transformation to monoanhydrogossypol (Fig. 2) was studied by A.I. Glushenkova and co-authors [14]. The latter has been proposed to react with diaminogossypol to produce naturally occurring pigment- gossypurpurin (Fig. 3), which also has unsymmetrical structure [15].

According to A.I. Glushenkova et al. [14], mono-anhydrogossypol can be obtained by heating gossypol solutions in methanol, ethanol, propan-1-ol and propan-2-ol at $50{ }^{\circ} \mathrm{C}$ for $40 \mathrm{~h}$. Mono-product with the highest yield was obtained in cases of using propan-1-ol and propan-2-ol (100\%). It is noteworthy that the formation of corresponding gossypol bis-product in propan-1-ol and propan-2-ol has not been observed even after 10 days and longer period. Paying attention to the fact that alcohols are even much weaker bases than amines, this phenomenon can be well explained in terms of afore-used acid-base conception. The results of these investigations have demonstrated a strong influence of temperature conditions and solvent type on gossypol's reactivity and, along with Abou Donia's research data on stability of gossypol in different solvents and in a wide range of temperature values [16] are highly important for synthesis of biologically active gossypol derivatives, which is conducted mostly in alcoholic solutions.

In 1987 Z.M. Guo et al. [17] reported on synthesis of mono-aldehyde gossypol (Table; 22) with higher antifertile activity than that of gossypol. This discovery was the first one implying the purposefulness and perspective of unsymmetrical modification approach to gossypol molecule for effective drug development. Later on, this direction in gossypol chemistry will be studied more intensively.

In 1997 S.A. Talipov and coworkers [1] reported on solid-state reaction conditions allowing to prepare unsymmetrical gossypol Schiff's bases with ammonia and methyl amine. The crystals of gossypol P3 polymorph 
used for this reaction have wide empty channels with one of gossypol's two aldehyde groups located near the channel wall, which makes possible to unsymmetrically modify gossypol molecule. Authors have demonstrated that this chemo-sorption is highly exothermic [1]; however, this fact has not been taken into consideration in order to optimize the yield of the target products. Moreover, none of the resulting gossypol half-Schiff bases has been tested for any biological activity. But despite these limitations as well as inefficiency of this technique for the reaction of gossypol with non-volatile amines, this original work was undoubtedly very valuable, suggesting a new, selective method of synthesizing gossypol half-Schiff bases.

Continuing this research work, B.T. Ibragimov et al. [18] could optimize this reaction yield (60-65\%) by applying low temperature conditions, and also, obtain an unsymmetrical gossypol half-Schiff base with ethyl amine (Table; 4). Based on UV-, IR- and ${ }^{1} \mathrm{H}$ NMR-spectroscopic data for all of these derivatives the enamine tautomeric form was predominantly suggested. In addition to this, K.Z. Tilyabaev with coworkers has demonstrated that gossypol half-Schiff base with ammonia has antifungal [19], antiradical [20] activity and at the same time it exhibits lower acute toxicity than gossypol itself [21]. The results of these investigations suggest the significance of free aldehyde groups present in the molecule of gossypol derivative for the biological activity exerted.

In 2005 K. Dodou et al. [2] reported on synthesis of enantiomeric gossypol half-Schiff bases with chiral aminoesters (Table; 18-21) by partial hydrolysis of corresponding bis-analogues. The yields of target products are $13-51 \%$. For all of them, except for that with L-tryptophan methyl ester substituent authors suggest enamine structure in deuterochloroform. However, no attempt was done to explain why racemic and enantiomeric gossypol bisand half-Schiff bases could exist as different tautomers in the same solvent as well as why opposite enantiomers of gossypol half-Schiff base with L-phenylalanine methyl ester synthesized at similar conditions are produced with such a different yield. The latter fact gives evidence of the different reactivity of gossypol enantiomers and certainly requires more exploration. The data on reported antipsoriatic activity of obtained mono-products suggest that it is much higher than that of their bis-analogues but lower than gossypol's. Authors conclude that this may indicate either the importance of free aldehyde groups for the anti-proliferative effect, or that the bis-Schiff bases have difficulty in entering the cell due to their size [2].

In order to synthesize unsymmetrical gossypol derivatives with non-volatile liquid and solid amines (Table; 58, 11, 12) K.Z. Tilyabaev with co-workers [22-25] used homogeneous reaction. They have investigated the process of unsymmetrical gossypol Schiff base formation. To create the same as in solid state reaction partial unavailability of gossypol's one aldehyde group for reaction with aminocompounds they applied high dilution technique, so amine was added to diluted gossypol solution that was cooled as well as amine solution. It is known that reaction of Schiff base formation is exothermic [1], which has been taken into account during experiment. Relatively low solubility of gossypol half-Schiff bases in chloroform and ethyl acetate at $-15{ }^{\circ} \mathrm{C}$ allowed applying precipitation followed by Silica gel column separation of target products. This method allowed synthesizing gossypol halfSchiff bases with non-volatile amines with relatively high yield. With some modifications of the afore-described method the gossypol mono-aldehyde product with barbituric acid (Fig.4) was synthesized [26].

Having monoanilinogossypol (Table; 5) synthesized according to above mentioned technique K.Z. Tilyabaev with co-workers obtained unsymmetrical gossypol bis-Schiff bases (13-16) with 100\% yield [6]. Another amine was introduced to monoanilinogossypol molecule by reaction with its free aldehyde group and its absence in the structures of products was registered by using ${ }^{1} \mathrm{H}$ NMR spectroscopy. Moreover, the effect of amine excess on the com-

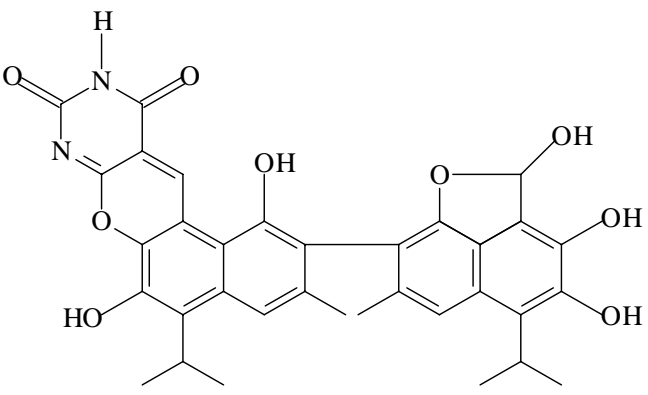

Fig. 4. Structure of gossypol mono-product with barbituric acid position of reaction mixtures has been investigated. It has been determined that reaction of amines with monoanilinogossypol (Table; 5) in a ratio of more than 1:1 causes replacement of aniline molecule from initial substrate which can be explained by relatively higher basicity of amines applied in excess.

The choice of solvent remains the most important factor for the synthesis of unsymmetrical gossypol derivatives. It's known that gossypol dissolved in methanol, ethanol and propan-1-ol forms half-acetals. This property of gossypol has been used by K.Z. Tilyabaev and co-workers [27] to attempt the synthesis of 
its half-Schiff bases. Previously A.I. Glushenkova et al. [28] investigated the reaction of gossypol acetals (Fig. 5; 34; $\mathrm{R}=\mathrm{Me}$ ) with $\mathrm{KOH}(\mathrm{aq})$, having demonstrated their stability in dilute $\mathrm{KOH}(\mathrm{aq})$ solutions. Amines, being much weaker bases than $\mathrm{KOH}$, have been expected not to react with acetal part of the molecule. It has been assumed that in gossypol half-acetal only a free aldehyde group will be attacked by nitrogen atom in amine molecule causing a strong C-N bond formation. Then, after evaporation of the solvent, acetal part of the product would turn either anhydro- or aldehyde form (if there is some water in the system) and amino-substituted part of the molecule would turn enamime tautomer. However, as reaction products, anhydrogossypol (Fig. 5; 35) and a symmetrical Schiff base (Fig. 5; 36) have been obtained.

Trying to synthesize gossypol half-Schiff bases with higher yield authors [27] used anhydrogossypol (Fig. $5 ; 35)$, a compound produced by dehydration of gossypol. In case of using anhydrogossypol a considerable increase of gossypol half-Schiff bases' yield was expected. However, if after reaction with amine furane ring (anhydro-structure) of the substrate was not opened, a possibility to synthesize a new type of compounds- unsymmetrical anhydrogossypol derivatives would appear.

It is noteworthy that theoretically in this reaction the remaining of furane ring (anhydro-structure) is highly possible because reaction of anhydrogossypol (Fig. 5; 35) with amines in contrast to that of gossypol is addition reaction and no water molecules that can open furane cycle are formed. The conduction of experiment with anhydrogossypol (Fig. 5; 35) and aniline (in conditions of monoanilinogossypol production) has demonstrated that reaction mixture finally has dianilinogossypol (Fig. 5; 36; $\mathrm{R}=-\mathrm{Ph}$ ) and anhydrogossypol (Fig. 5; 35) in almost equal quantities with a negligible content of monoanilinogossypol (Fig. 5; 5a; R= -Ph). K.Z. Tilyabaev et al. [27] also tried to obtain monoanilino-monoanhydrogossypol (Fig. 5; 37; R= -Ph) from prepared monoanilinogossypol (Fig. 5; 5a; $\mathrm{R}=-\mathrm{Ph}$ ) by heating its $\mathrm{m}$-xylene solution under reflux (the same technique is used to synthesize anhydrogossypol from gossypol). However, as the products of this reaction dianilinogossypol (Fig. 5; 36; R= $-\mathrm{Ph}$ ) and anhydrogossypol (Fig. 5; 35) were formed.

The attempts to synthesize unsymmetrical gossypol derivatives in alcohol solutions, by using anhydrogossypol and also by dehydrating monoanilino-gossypol resulted in formation of anhydrogossypol and its symmetrical derivatives. Theoretically all reactions are going through the formation of monoanhydro-intermediates (Fig. 5; 37). Their instability [29] probably causes disproportioning and above mentioned products' formation.

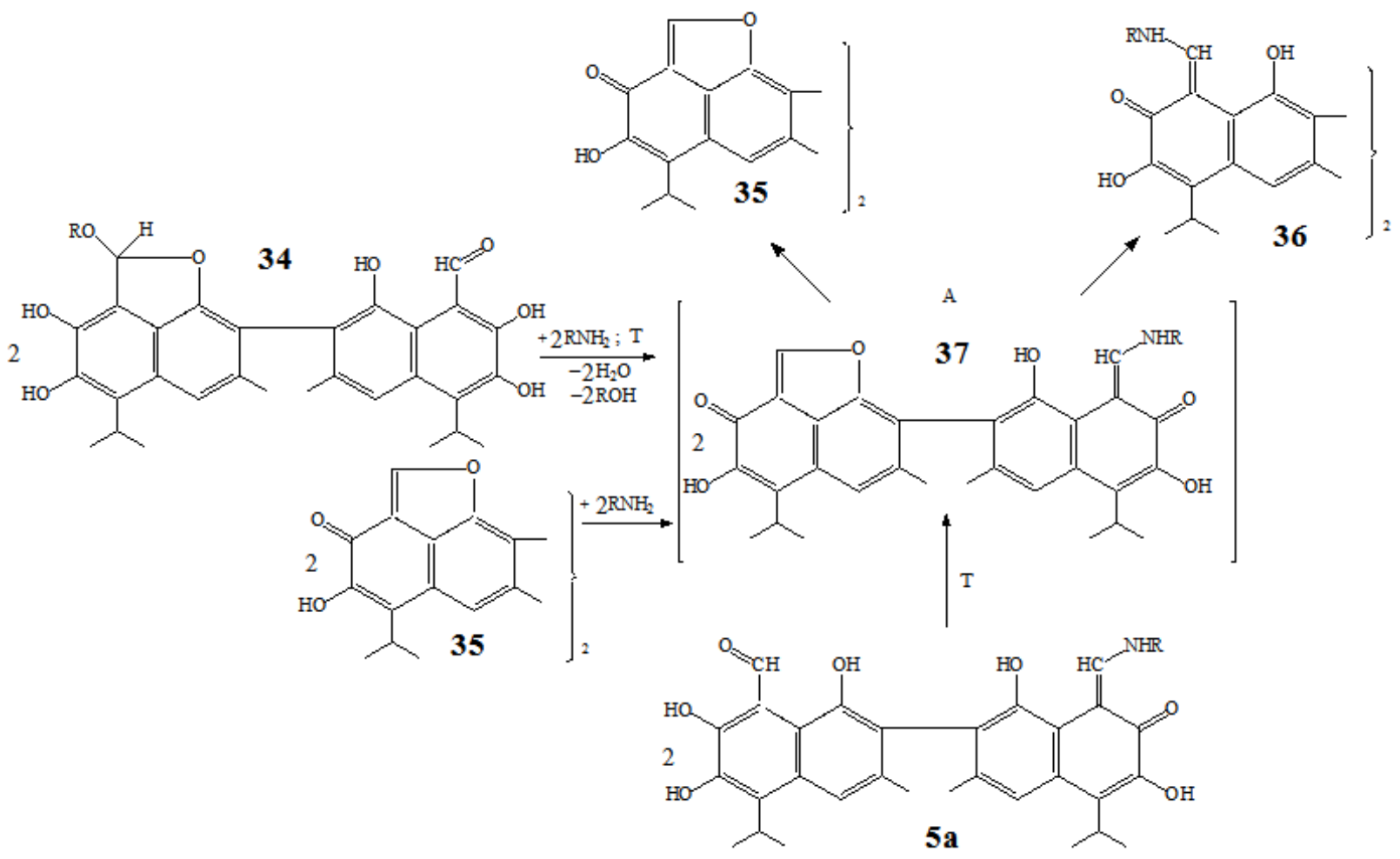

Fig. 5. Summary scheme of all reactions going through the formation of mono-anhydrointermediates proposed by K.Z. Tilyabaev et al. [27] 
In order to study factors that affect the reaction of gossypol half-Schiff base formation K.Z. Tilyabaev et al. [30] investigated the interaction of gossypol with 4-aminoantipyrine. It has been determined experimentally that in order to optimize the yield of gossypol half-Schiff base with 4-aminoantipyrine (Table; 11) the reaction should be conducted either at low temperature or by diluting reaction mixture with an appropriate solvent (chloroform). Acetone being more basic than chloroform appears to shift acid-base equilibrium towards reaction products increasing the yield of symmetrical derivative. All above mentioned factors prevents both gossypol aldehyde groups from quick interaction with 4-aminoantipyrine increasing the possibility of unsymmetrical products' formation.

Structural investigations of newly synthesized unsymmetrical gossypol Schiff bases by UV-, IR- and ${ }^{1} \mathrm{H}$ NMR-spectroscopy methods have allowed K.Z. Tilyabaev et al. to suggest that they (to put more precisely, their amino-substituted part) exist predominantly as enamine tautomer (Fig. 6; 39) [21]. By X-ray investigation of cocrystals of gossypol half- and bis-Schiff bases with 4-aminoantipyrine grown from reaction mixture existence of corresponding half-Schiff base as enamine tautomer (Fig. 6; 39; $\mathrm{R}=-$ Ant) in a solid state also has been established. The results of X-Ray investigation suggests that gossypol half- and bis-Schiff bases with 4-aminoantipyrine are co-crystallized from reaction mixture in a ratio of $2: 1$ [31]. Non-substituted part of the molecules of synthesized gossypol half-Schiff bases exist mostly as aldehyde tautomer, however, in DMSO- $\mathrm{d}_{6}$ it turns lactol tautomer (Fig. 7), which is typical for gossypol itself in this solvent. It is interesting that «classical» imine tautomer (Fig. 6; 38) was observed only for gossypol half-Schiff base with 4-aminoantipyrine (Table; 11) in $\mathrm{CDCl}_{3}(11,05$ ppm, s., $\mathrm{CH}=\mathrm{N}-$ ). Based on ${ }^{1} \mathrm{H}$ NMR- and IR-spectroscopic data for gossypol monoproduct with barbituric acid authors assume that the intramolecular dehydration accompanying the reaction resulted in a heterocycle joining the gossypol backbone with the substituent (Fig. 4) [21].

Results of comparative studies of acute toxicity [21], antifungal activity [19] and cytotoxicity on K562 human leukemia line cells [32] of gossypol and its Schiff bases suggest that, in general, the less is number of free aldehyde groups the lower is the activity of compound (gossypol>gossypol half-Schiff bases > gossypol bis-Schiff bases). Studies on antiradical and membranotropic activity [33] of investigated compounds also confirmed the above-mentioned correlation.

Unsymmetrical aldehyde derivatives of gossypol seem to be very promising candidates for effective drug discovery, but the information about them is still very limited. Not all of them have been tested for biological activity. In addition to this, the most of unsymmetrical gossypol aldehyde derivatives being synthesized are Schiff bases. However, unsymmetrical derivatization of gossypol's aldehyde groups may include their reaction with compounds containing active hydrogen (e.g. ethyltrifluoromethylacetylacetone [34]), preparation of thioderivatives [35], further synthesis of mixed derivatives by using the polyfuctionality of gossypol molecule (e.g. glycosides of unsymmetrical gossypol imines) or application of the same principles to the modification of gossypol derivatives containing free aldehyde groups, e.g. gossypolone (Fig. 8; 40) All of these as well as other numerous possibilities to functionalize gossypol's aldehyde groups remain totally unexplored.

Gossypol mono-azoderivatives. A.L. Markman et al. [36] first reported on reaction of gossypol with diazotized amines, where by controlling their stoichiometric ratio either mono (Table; 23-25) - or bis-adducts can be prepared. However, I.P. Nazarova et al. [37] reported on synthesis of gossypol mono-azoderivatives (Table; 26-30) by applying the excess of diazonium salts. It has to be noted that these reactions have been carried out at low temperature being similar to that used for the direct synthesis of gossypol half-Schiff bases [18]. Moreover, according to the mechanism of this reaction suggested [38], gossypol 1,1'-hydroxyl groups appear to play certain role in this electrophilic substitution. Knowing that gossypol is a diprotic acid due to the presence of 1,1'-hydroxyls whose acidity and hence, the nucleophilicity of corresponding oxygen atoms varies considerably one from another, it can explain why even by employing the excess of diazonium salt only gossypol mono-azoderivatives can be synthesized.

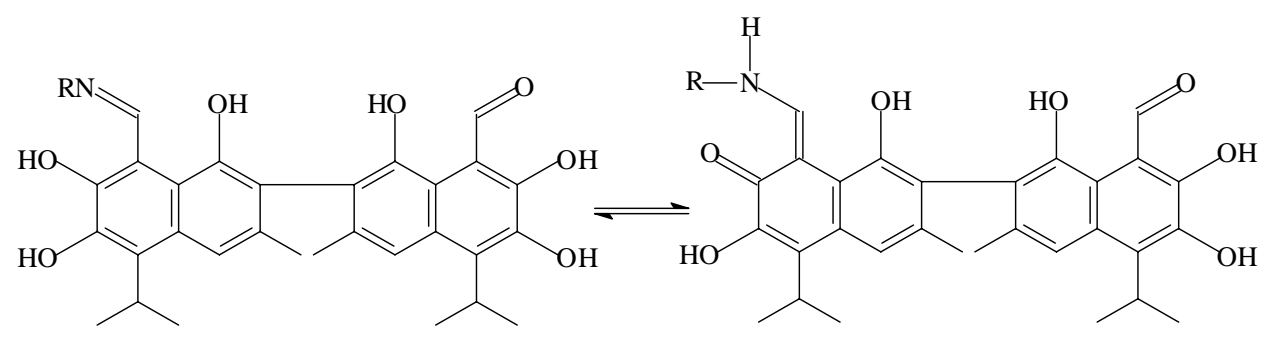

(38)

Fig. 6. Imine (38) - enamine (39) tautomeric equilibrium of gossypol half-Schiff bases 
It has to be noted that in contrast to gossypol bisazoderivatives the existence of their mono-analogs as hydroxyazo- or quinonhydrazo-tautomers was not outlined.

There are no reports on biological activity of gossypol mono-azoderivatives. However, K.Zh. Rezhepov et al. [39] have demonstrated low interferon-inducing activity for symmetrical bis-azoderivatives of gossypol and the induction of high titres of interferon by imines of gossypol bis-azoderivatives. In this view, the synthesis of gossypol mono-azoderivatives and their monoimines is of a certain interest, because will provide an opportunity to investigate their biological activity in comparison with that of their symmetrical analogues and possibly reveal some promising agents as well as to elucidate, whether the amine is introduced to the substituted on non-substituted part of the mole-

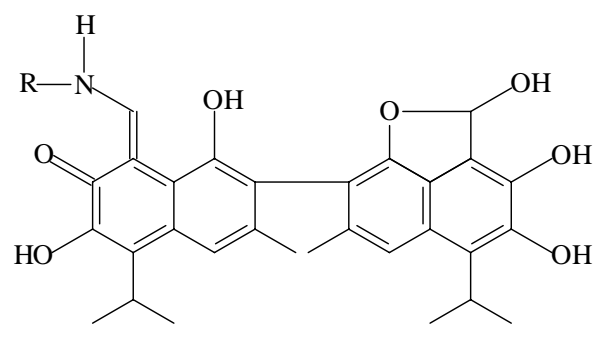

Fig. 7. Lactol tautomer of unsubstituted part of gossypol monoaminoderivatives in $\mathrm{DMSO}_{6}$ cule and how it affects the biological effect of the product.<smiles>CC(C)c1c(O)c(O)c(C=O)c2c1C(=O)C1=C(C2)C2=C(C1=O)C1C(=O)c3c(C=O)c(O)c(O)c(C(C)C)c3C(=O)C21</smiles>

(40)<smiles>CC(C)C1=C(O)C(=O)/C(=C\O)C2=C1C(=O)C1=C(C2=O)C2C(=O)c3c(c(C=O)c(O)c(O)c3C(C)C)C(=O)C12</smiles>

(40a)

Fig. 8. Structures of gossypolone (40) and its mixed tautomer (40a)

Unsymmetrical hydroxyl derivatives of gossypol. There are some scanty data on unsymmetrical gossypol hydroxyl derivatives. In 1992 H. Xue et al. [40] reported on synthesis of gossypol 6-O-methyl ether (Table; 31), which was isolated as its complex with sodium tetraborate along with gossypol 6,6'-dimethyl ether. Both substances were identified by R. Stipanovic et al. [41] as natural products of G. barbadense seeds. 6- methoxygossypol has been shown to exert higher anticancer activity than gossypol to some extent [42]. It also has been found that in contrast to gossypol, 6-methoxygossypol is a potent $\alpha$-amylase inhibitor [7].

Recently J. Yin and co-authors [7] have reported on newly synthesized gossypol O-diglycosides with substituents at positions 6 and 7' prepared by ultrasound-assisted reaction. The traces of gossypol monoglucoside tetraacetate were also present in reaction mixture, though authors did not specify whether it was 6- or 7-monoglucoside tetraacetate. UV- and NMR-spectroscopic data allowed authors suggesting the unsymmetrical structures of 6,7'-gossypol diglucoside tetraacetate (Table; 32) and 6,7'-gossypol diglycoside (Table; 33). It is interesting that 6,7'-gossypol diglucoside tetraacetate exists even in $\mathrm{CDCl}_{3}$ solution as lactol tautomer. For 6,7'-gossypol diglycoside an aldehyde tautomer was suggested. These compounds have been tested for anticancer and anti-trypanosomal activities. Anticancer activity results suggest that gossypol 6,7'-diglycoside tetraacetate (Table; 32) inhibits cancer cell growth with a reduced cytotoxicity to normal cells comparable to unmodified gossypol. Gossypol 6,7'-diglycoside tetraacetate (Table; 32) has been shown to be effective against the $T$. bruce $i$ with considerably lower $\mathrm{LD}_{50}$ value compared with the unmodified gossypol and gossypol diglycosides. Authors hypothesize that such a behavior of gossypol 6,7'-diglycoside tetraacetate (Table; 32) may be caused by its existence as a lactol tautomer, which prevents it from the Schiff base formation with proteins and possibly can contribute to its potent inhibitory effect on T. brucei cell growth. In contrast, the aldehyde function is said to result a weaker inhibition.

According to N.I. Baram et al. [43] in contrast to gossypol methyl ethers, where all 6 hydroxyls can be methylated, their complete glycosylation appears to be impossible primarily due to steric hindrance. It is suggested that the maximum of 4 galactose moieties can be introduced to gossypol molecule. In conjunction with results reported by J. Yin [7], who postulated that gossypol derivatives with a low degree of methylation having increased lipophilic affinity to cancer cells may display a higher cytotoxicity, the partial unsymmetrical glycosylation of gossypol, which also may give products with increased solubility, seems to be very promising approach for effective drug development. 


\section{Other unsymmetrically functionalized derivatives of gossypol}

Speaking of gossypol bis-derivatives with unsymmetrically positioned substituents, some related halogenation products have to be noted. In 1992 G.-D. Zhu et al. [44] reported on synthesis of several bromoderivatives prepared from apogossypol hexamethyl ether (Fig. 9; 41). It has been established that the usage of different brominating agents causes the formation of different products. Thus, by using $\mathrm{Br}_{2}$ in the presence of $\mathrm{Fe}$ powder at low temperature conditions the compound $\mathbf{4 2}$ (Fig. 9) was produced. Other techniques involving ultrasound-assisted bromination, reactions with $\mathrm{N}$-bromosuccinimide and pyridinium bromide perbromide gave only symmetrical products. Interestingly, in contrast to results obtained by G.-D. Zhu et al. [44], the reaction with N-bromosuccinimide carried out by J. Zhang with coworkers [8] produced unsymmetrical 4,8'-dibromoapogossypol hexamethyl ether (Fig. 9; 43). Another unsymmetrical derivative 45 (Fig. 10), which is related to the same series is heterocyclic product formed by reaction of $\mathbf{4 4}$ (Fig. 10) with AgF. Authors suggest that $\mathbf{4 4}$ (Fig. 10) may easily undergo hydrolysis. Therefore, intramolecular dehydration of hydrolyzed product followed by partial oxidation can possibly result in formation of $\mathbf{4 5}$ (Fig. 10).

All of these compounds were not reported to have any biological effect, however they were said to be valuable synthons for preparation of gossypol fluoroderivatives that might be biologically active.

Interesting approach to the synthesis of unsymmetrical gossypol related compounds has been suggested by N.T T. Chau et al. [45-47], who has succeeded the addition of 2 naphthalene rings with different substituents (Fig. 11). Theoretically, this method provides an opportunity to synthesize gossypol related compounds of desired structure and hence, it appears to be very effective for gossypol based drug design.

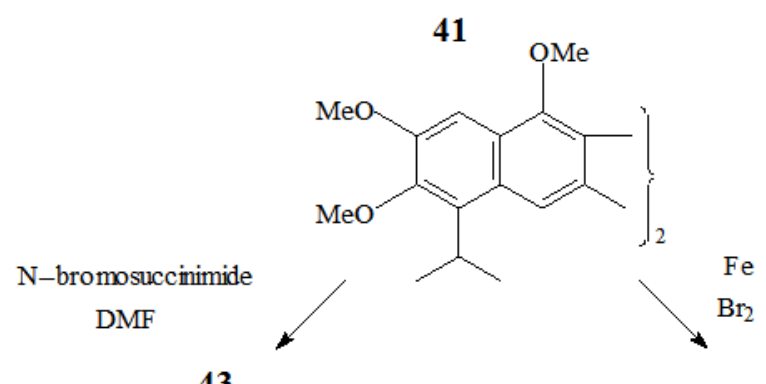

43

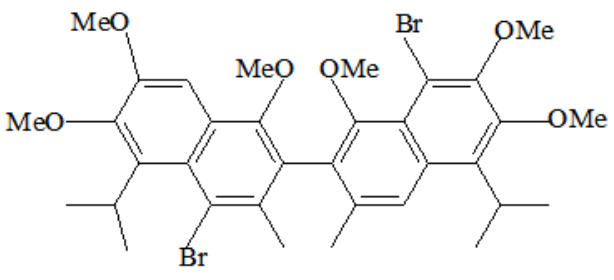

Fe
42

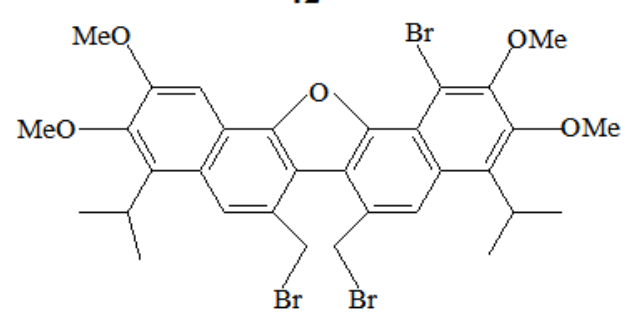

Fig. 9. Unsymmetrical products of bromination of apogossypol hexamethyl ether (41)

Fig. 10. Scheme of reaction leading to unsymmetrical heterocyclic product formation

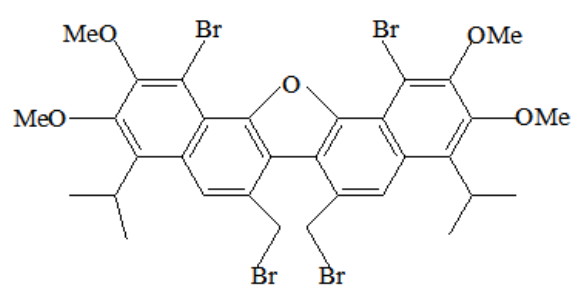

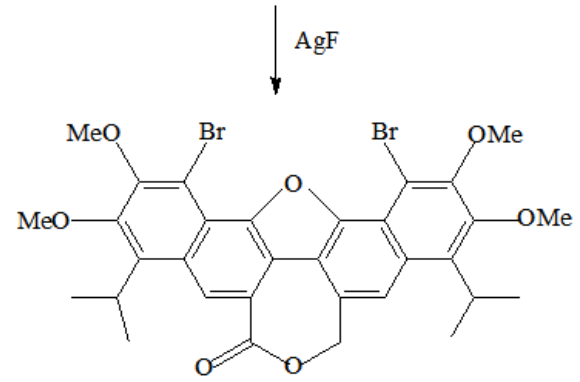




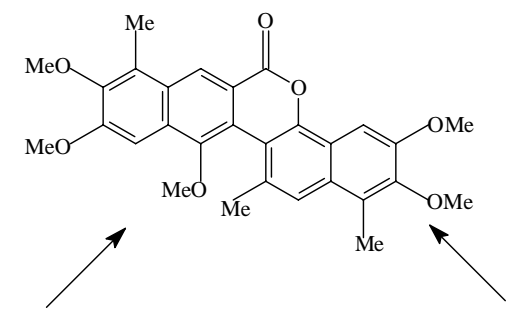<smiles>COc1cc2c(OC)c(OC)c(OC)c(OC)c2cc1C(=O)Oc1cc(C)cc2cc(C)c(OC)c(C)c12</smiles>

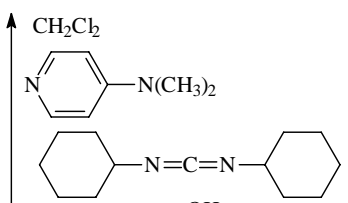<smiles></smiles><smiles>COc1cc2c(O)cc(C)cc2c(C#N)c1OC</smiles><smiles>COc1cc2c(OC(=O)c3cc(OC)c4c(OC)cc(OC)c(OC)c4c3)c(Br)c(C)cc2c(C)c1OC</smiles><smiles>CN(C)c1cccc(CN=C=NC2CCCCC2)c1</smiles><smiles>COc1cc(OC)c2c(OC)cc(C(=O)O)cc2c1C</smiles><smiles>COc1cc2c(O)c(Br)c(C)cc2c(OC)c1[N+]#N</smiles>

Fig. 11. Reaction schemes describing the formation of unsymmetrical gossypol-related compounds from condensation of 2 naphthalene moieties with different substituents

Asymmetry of gossypol derivatives induced by mixed tautomerism. Dimeric structure of gossypol and its symmetrical derivatives presumes a possible formation of mixed tautomeric forms within the same molecule. For gossypol itself such mixed tautomers have not been isolated, however, some informative data have been obtained on gossypol (Fig. 12), gossypolone (Fig. 8; 40a) and diethylaminogossypol (Fig 13) hybride tautomers by studying conformations and inversion pathways leading to their racemization with MM3 [48]. Thus, it has been revealed that hybrid tautomers of gossypol (Fig. 12) often have energy barriers between those of their respective symmetrical tautomers. It has been also suggested that the easier inversion of gossypolone comparatively to that of gossypol occurs preferentially when gossypolone exists as mixed tautomer (Fig 8; 40a).

For some other symmetrical derivatives of gossypol hybrid structures have been also assigned. T.R. Seshadri et al. [49] have first demonstrated the existence of gossypol hexamethyl ether in monoaldehyde-monolactol form (Fig. 14), which has been synthesized later by K.P.P. Nguyen with co-workers [50] in a high yield via solidliquid phase transfer catalysis without solvent. Gossypol hexaacetate also has been shown to exist as monoaldehyde-monolactol tautomer (Fig. 15). Its S- and R-isomers (Fig. 15; 46, 46a) have been isolated and fully characterrized by Jaroszewski et al. [51]. N. Kunesch et al. [5] based on ${ }^{1} \mathrm{H}$ NMR-spectroscopic data, suggested the existence of gossypol macrocyclic Schiff bases with spermidine (Fig. 16; 47) and putrescine (Fig. 16; 48) as monoimino-monolactol tautomers in minor quantities. Interestingly, no mixed tautomers of symmetrical gossypol derivatives involving ketol or enamine form have been observed. Moreover, no information on their specific biological activities has been reported, though due to dynamic nature of solvent-dependent tautomeric equilibrium and energetically low barriers of transitions from the hybrid tautomers to their symmetrical analogues the biological effect of "pure" mixed tautomer will be difficult to estimate.

Speaking about further use of gossypol derivatives as unsymmetrical tautomers limited by their stability predominantly in solvent-free conditions, they appear to be effective starting materials for solid state synthesis, which possibly will allow preparing novel functionalized derivatives with interesting properties. For instance, mono-aldehyde derivatives could be selectively prepared from monoaldehyde-monolactol tautomers of gossypol ethers and esters. 


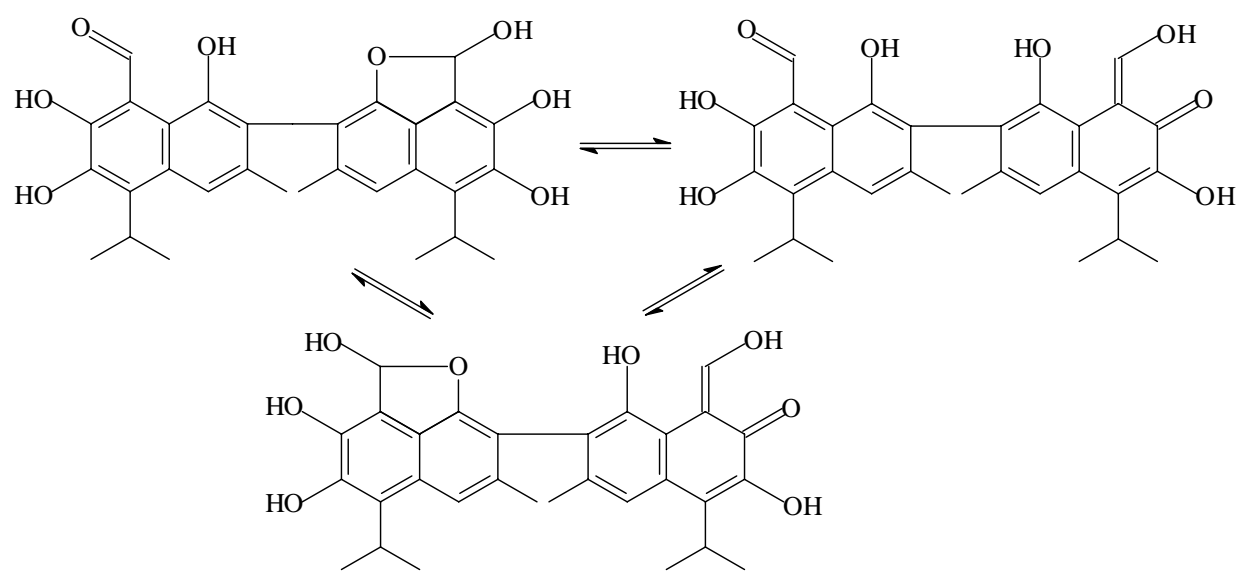

Fig. 12 Structures of gossypol mixed tautomers<smiles>CCCN/C=C1\C(=O)C(O)=C(C(C)C)c2cc3c(c(O)c21)-c1c(cc2c(C(C)C)c(O)c(O)c(C=NCC)c2c1O)C3</smiles>

Fig. 13. Structure of diethylaminogossypol mixed tautomer

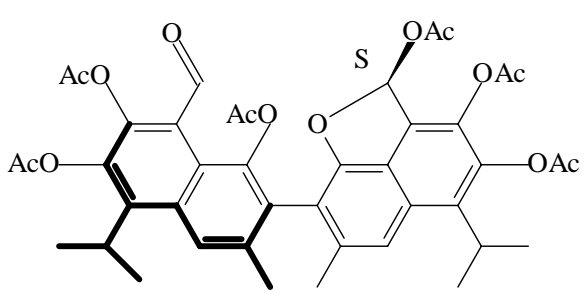

(46)<smiles>COc1c(OC)c(C=O)c2c(OC)c3c(cc2c1C(C)C)Cc1cc2c(C(C)C)c(OC)c(OC)c4c2c(c1-3)OC4OC</smiles>

Fig. 14. Gossypol hexamethyl ether as monoaldehydemonolactol tautomer

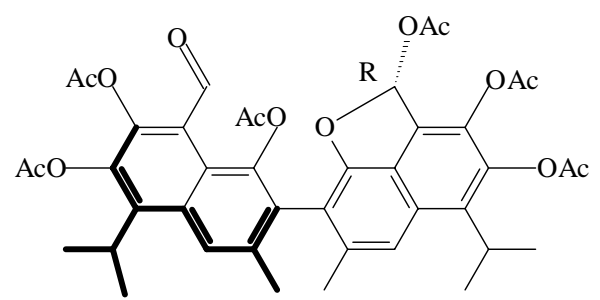

(46a)

Fig. 15. Structures of S (46), R (46a) -monoaldehyde-monolactol tautomers of gossypol hexaacetate<smiles>Cc1cc2c(C(C)C)c(O)c(O)c(/C=N/OCl)c2c(O)c1-c1c(C)cc2c(C(C)C)c(O)c(O)c3c2c1OC3NO</smiles>

$\mathrm{X}=-\left(\mathrm{CH}_{2}\right)_{4^{-}}(\mathbf{4 7}) ;-\left(\mathrm{CH}_{2}\right)_{3} \mathrm{NH}\left(\mathrm{CH}_{2}\right)_{4}-(48)$
Fig. 16. Structures of monoimino-monolactol tautomers of gossypol macrocyclic Schiff bases with spermidine (47) and putrescine (48) 


\section{Summary. Future directions}

Gossypol has been intensively studied for over the last 100 years. Its chemical transformation has allowed preparing numerous derivatives including unsymmetrical ones that have been found to be more potent than their respective symmetrical analogs as antiradical, antioxidant, anticancer, antifungal agents. The results of these investigations give opportunity to search for physiologically active compounds and to develop methods of synthesizing substances with desired properties considering their effect on molecular and cellular levels. This direction in gossypol chemistry is undoubtedly perspective, since:

- as afore-said, it broadens the range of potential drugs, requiring though at the same time more detailed biological investigations;

- it allows to use unsymmetrical mono-derivatives of gossypol as starting materials to prepare unsymmetrical bis-products, which possibly leads to synthesis of derivatives with retained biological activity and reduced toxicity; however, it needs to be checked, whether, e.g. the compound consisting of both 4-aminoantipyrine and sodium $\beta$-aminoethylsulfonate fragments that are present in antiviral «Ragosin» and immunosuppressant «Megosin» preparations respectively, will have the effect of both or absolutely different properties;

- racemic unsymmetrical gossypol derivatives can be separated into enantiomers (they also can be synthesized from (+)- and (-)-gossypol analogically to racemate), which will allow estimating the contribution of each to the activity exhibited by racemate and also revealing potentially active compounds;

All these are ideas that can be suggested for further exploration.

\section{References}

1. Talipov S.A., Manakov A., Ibragimov B.T., Lipkowski J., Tiljakov Z.G. J. Inclusion Phenom. Macrocyclic Chem., 1997, vol. 29, pp. 33-39.

2. Dodou K., Anderson R.J., Lough W.J., Small D.A.P., Shelley M.D., Groundwater P.W. Bioorganic \& Medicinal Chemistry, 2005, vol. 13, pp. 4228-4237.

3. Shirley D.A., Sheehan W.C. J. Org. Chem., 1956, vol. 21, pp. 251-252.

4. Kim I., Marcelle G.B., Waller D.P., Cordell G.A., Fong H.H.S. Contraception, 1987, vol. 35, pp. $289-297$.

5. Kunesch N., Barbier M.P., Dalkafouki A., Poisson J.E. Ann. Pharm. Fr., 1990, vol. 48, pp. 1-6.

6. Tilyabaev K.Z., Yuldashev A.M., Ibragimov B.T., Talipov S.A., Kamaev F.G., Dowd M.K. Reports of AS Ruz, 2009, vol. 1, pp. 47-49. (in Russ.).

7. Yin J. Chemical modification and biological activity exploration of the natural product- gossypol: PhD dissertation in Food technology, Graduate School of Clemson University, USA, 2010. 167 p.

8. Zhang J., Matlin S.A. Zhongguo Yaoke Daxue Xuebao, 1993, vol. 24, pp. 178-179.

9. Karrer P., Tobler E. Helv. Chim. Acta, 1932, vol. 15, pp. 1204-1212.

10. Dechary J.M., Brown L.E. J. Am. Oil Chem. Soc., 1956, vol. 33, pp. 76-78.

11. Lide D.R. Handbook of Chemistry and Physics. $88^{\text {th }}$ edition. New York; 2008. 2640 p.

12. Alley P.W., Shirley D.A. J.Org. Chem., 1959, vol. 24, pp. 1534-1536.

13. Carruth F.E. J. Am. Chem. Soc., 1918, vol. 40, pp. 647-663.

14. Glushenkova A.I., Nazarova I.P., Ul'chenko N.T., Kristallovich E.L. Chem. Nat. Compd., 1989, vol. 5, pp. 607-610.

15. Glushenkova A.I., Nazarova I.P., Ul'chenko N.T., Zaborskaya I.N. Chem. Nat. Compd., 1988, vol. 24, pp. 601-603.

16. Nomeir A., Abou-Donia M.B. J. Am. Oil Chem. Soc., 1982, vol. 59, pp. 546-549.

17. Guo Z.M., Wan F., Gu Z.P., Wu G.P., Peng S.X. Yao Хие Хие Вao, 1987, vol. 22, pp. 597-602.

18. Patent IAP 04032B (Uzbekistan). 2009.

19. Tilyabaev K.Z., Arzanova I.A., Yuldashev A.M., Ibragimov B.T., Talipov S.A. Uzbek biological journal, 2009, vol. 4, pp. 7-10.

20. Gayibov U.G., Tilyabaev K.Z., Salakhutdinov B.A., Yuldashev A.M., Talipov S.A., Ibragimov B.T. Uzbek biological journal, 2009, vol. 3, pp. 3-6.

21. Tilyabaev K.Z., Kamaev F.G., Vypova N.L., Yuldashev A.M., Ibragimov B.T., Talipov S.A. Russian Journal of Bioorganic Chemistry, 2010, vol. 36, pp. 390-395.

22. Tilyabaev K.Z., Yuldashev A.M., Ibragimov B.T. Materials of scientific works of young scientists (Biology and Chemistry), Tashkent, 2006, pp. 166-168. (in Russ.).

23. Tilyabaev K.Z., Yuldashev A.M., Ibragimov B.T., Talipov S.A., Kamaev F.G. Proceedings of 2-nd International Conference «Chemistry, technology and medical aspects of natural compounds». Almaty, 2007, p. 252.

24. Tilyabaev K.Z., Yuldashev A.M., Ibragimov B.T., Talipov S.A., Kamaev F.G. Proceedings of 4-th Russian conference «New achievements in chemistry and chemical technology of plant materials», Barnaul, 2009, pp. 58-59. (in Russ.).

25. Tilyabaev K.Z., Yuldashev A.M., Ibragimov B.T., Talipov S.A., Kamaev F.G. Proceedings of 7-th Russian conference «Chemistry and medicine, Orchimed-2009», Ufa, 2009, pp. 280-281. (in Russ.). 
26. Tilyabaev K.Z., Yuldashev A.M., Ibragimov B.T., Talipov S.A., Kamaev F.G. Proceedings of Republic conference with International participation "Current issues on chemistry of natural compounds», Tashkent, 2009, pp. 73. (in Russ.).

27. Tilyabaev K.Z., Yuldashev A.M. Materials of Scientific works of young scientists (Biology and Chemistry), Tashkent, 2006,. pp. 164-166. (in Russ.).

28. Glushenkova A.I., Nazarova I.P., Ul'chenko N.T., Abdullaev N.D. Chem. Nat. Cmpd., 1993, vol. 29, pp. 451-453.

29. Tilyabaev K.Z., Yuldashev A.M., Ibragimov B.T., Talipov S.A., Kamaev F.G. Proceedings of Republic scientific conference «Physiologically active compounds of plant resources and technology of inorganic compounds», Nukus, 2008, pp. 57-59. (in Russ.).

30. Tilyabaev K.Z. Reports of AS Ruz., 2009, vol. 5, pp. 55-58. (in Russ.).

31. Tilyabaev K.Z., Yuldashev A.M., Ashurov J.M., Talipov S.A., Ibragimov B.T. Proceedings of 8-th International Symposium on the Chemistry of Natural Compounds, Eskişehir, 2009, p. 90.

32. Tilyabaev K.Z., Yuldashev A.M., Ibragimov B.T., Talipov S.A. Proceedings of Scientific conference «Biologically active compounds: fundamental aspects of obtaining and application», Novy Svet, 2009, pp. 431-432. (in Russ.).

33. Tukfatullina I.I., Tilyabaev K.Z., Mamadrakhimov A.A., Salakhutdinov B.A., Kamaev F.G., Yuldashev A.M., Dowd M.K., Talipov S.A., Ibragimov B.T., Aripov T.F. Chem. Nat. Cmpd., 2008, vol. 44, pp. 440-445.

34. Gusev D.V., Kadyrov A.A., Shelud'ko M.O., Veshkurova O.N., Maksimov V.V., Uzbekov V.V., Salikhov Sh.I., Peregudov A.S., Antipin M.Yu., Lysenko K.A., Chkannikov N.D. Proceedings of Russian conference on fluorine chemistry, Moscow, 2008, p. 52. (in Russ.).

35. Dao V-T., Dowd M.K., Gaspard C., Martin M-T., Hémez J., Laprévote O., Mayer M., Michelot R. J. Bioorganic \& Medicinal Chemistry, 2003, vol. 11, pp. 2001-2006.

36. Markman A.L., Rzhekhin V.P. Gossypol and Its Derivatives: Pishchevaya Promyshlennost, Moscow, 1965. 246 pp.

37. Nazarova I.P., Glushenkova A.I., Markman A.L. Khim. Prir. Soedin., 1976, pp. 607-609. (in Russ.).

38. Kenar J.A. J. Am. Oil Chem. Soc., 2005, vol. 83, pp. 269-302.

39. Rezhepov K.Zh., Ziyaev Kh.L., Baram N.I, Kamaev F.G., Levkovich M.G., Saiitkulov A.M., Ismailov A.I. Khim. Prir. Soedin., 2003, pp. 289-291.

40. Xue H., Guo Z., Kon A., Wu G. Chin. Chem. Lett., 1992, vol. 3, pp. 165-166.

41. Stipanovic R.D., Bell A.A., Mace M.E., Howell C.R. Phytochemistry, 1975, vol. 14, pp. 1077-1081.

42. Wang X., Beckham T.H., Morris J.C., Chen F., Gangemi J.D. J. Agric. Food. Chem., 2008, vol. 56, pp. $4393-4398$.

43. Baram N.I., Yuldasheva M., Ismailov A.I ., Sadykov A.S. Khim. Prir. Soedin., 1972, pp. 126-127.

44. Zhu G.-D., Chen D.-H., Huang J.-H., Chi C.-S. J. Org. Chem., 1992, vol. 57, pp. 2316-2320.

45. Chau N.T.T. Synthèse totale racémique d'analogues structuraux du gossypol et de l'apogossypol mettant en jeu des reactions de métallation aromatique: These pour obtenir le grade de Docteur an Specialite: Chemie fine-Chemie organique, Université du Maine, France, 2008, 144 p.

46. Nguyen T.H., Chau N.T.T., Castanet A.-S., Nguyen K.P.P., Mortier J. Org. Lett., 2005, vol. 7, pp. 2445-2448.

47. Nguyen T.H., Chau N.T.T., Castanet A.-S., Nguyen K.P.P., Mortier J. J. Org. Chem., 2007, vol. 72, pp. 3419-3429.

48. Beisel C.L., Dowd M.K., Reilly P.J. Journal of Molecular Structure: THEOCHEM, 2005, vol. 730, pp. 51-58.

49. Seshadri T.R., Sharma N.N. Curr. Sci., 1973, vol. 42, pp. 821-822.

50. Nguyen K.P.P., Ton T.Q., Nguyen N.S., Pham D.H. Tap Chi Hoa Hoc., 1997, vol. 35, pp. 93-96.

51. Jaroszewski J.W. Cornett C., Strom-Hansen T. Gossypol, in NMR Spectroscopy in Drug Resarch. Proceedings of the Alfred Benzon Symposium 26: Copenhagen, 1988, pp. 75-100. 
